短—報

ササゴイ Butorides striatus の部分白化例

風 間 辰 夫*

\title{
An example on partial albinism of the Amur Green Heron
}

Tatsuo KAZAMA

Summary: An albino of the Amur Green Heron, Butorides striatus was collected at Niigata

Prefecture. Albino of this species in very rare.

キジ Phasianus colchicus, ヤマドリ Phasianus Soemmerrinqii, スズメ Passer montanus, ハシボソガ ラス Corvus corone, ツバメ Hirundo rustica などの 白化及び部分白化はたびたび，新聞やテレビのニュース としてとりあげられている。本種の白化等に関する例は 文献などでもほとんど見当たらず, 新潟県では初めての ことであり, 特に本例の場合は極めて珍らしい白色変化 (Fig. 1) をしているので貴重と思われる。

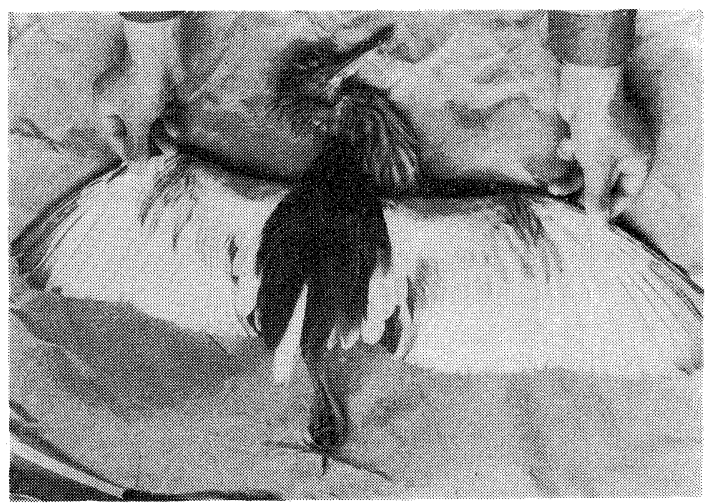

Fig. 1. Parital albinism of jurenile Amur Green Heron

\section{1. 保護捕獲の状況}

1973 年 12 月 13 日, 新潟県佐渡郡羽茂町大字大石海 岸で弱ってうずくまっていたのを, 羽茂中学校野鳥保護 委員の生徒達によって保護捕獲された。生徒達は学校で 保護飼育したが翌 14 日に死亡したため, 筆者に同定と, はく製標本にしてくれと送付してきたものである。

\section{2. 各部測定及び解剖結果}

採集日・性・歯令：1973 年 12 月 13 日, 雄幼鳥

* 新潟市新潟県きじ養殖場兼傷病鳥救護舎 $\mathbf{\%} 950-21$

Pheasant Farm \& Bird Hospital of Niigata Pref.
採集地 : 新潟県佐渡郡羽茂町大石海岸

採集者・羽茂中学校野鳥保護委員

測定 : 翼長 $228 \mathrm{~mm}$, 尾長 $79 \mathrm{~mm}$, 嘴峯 $64 \mathrm{~mm}$, 跗蹠 $59 \mathrm{~mm}$, 尾羽 12 枚, 体重 $280 \mathrm{~g}$

解剖結果 : 本個体は普通体のササゴイに比べ極めて大き く、ゴイサギに近い大きさであった。特に死亡し た後の体重 $280 \mathrm{~g}$ があったことから，生前は 300 $\mathrm{g}$ を越えていたものと思われる。内臓は全く異状 なく, 外傷は頭部から頸部に生活反応を示す内出 血のあことがありこれが死因と思われた。

\section{3. 白化の状態}

（1）嘴峯，下嘴の基部はミドリ色十黄色，上嘴と下嘴の 先端は黒色

（2）虹彩：黄色であり正常

（3）頭部から背部は幼鳥羽の普通色

(4) 腹部は全部白色

（5）尾羽は４枚の先端がわずかに灰色

（6）両翼は左右対称に白化している

（7）脚部は普通個体と同じく正常

\section{4. 考 察}

本個体の部分白化は，1967 年（鳥 18, 83 号）蓮尾喜 彪氏によるオオミズナギドリの斑白化例による白化と全 く同じように, 左右対称の白化現象をしており，極めて 興味ある例と思われる。

なおササゴイの新潟県における記録は極めて少なく, 特に幼鳥の記録は本例を含め 2 例しかない。なお佐渡ケ 島においては個体採集は初めてで, 観察と合わせて 2 回 目の記録である。

(Received Mar. 18, 1974) 